\title{
PRELIMINARY REPORT ON ENGINEERING PROPERTIES AND ENVIRONMENTAL RESISTANCE OF ANCIENT MUD BRICKS FROM TELL EL-RETABA ARCHAEOLOGICAL SITE IN THE NILE DELTA
}

\author{
Jerzy Trzciński ${ }^{1}$, Malgorzata Zaremba ${ }^{1}$, Slawomir Rzepka ${ }^{2}$, Fabian Welc ${ }^{3}$, Tomasz Szczepański ${ }^{1}$ \\ ${ }^{1}$ Institute of Hydrogeology and Engineering Geology, Faculty of Geology, University of Warsaw, \\ Żwirki i Wigury 93,02-089 Warsaw, Poland, e-mail: jerzy.trzcinski@uw.edu.pl \\ ${ }^{2}$ Institute of Archaeology, University of Warsaw, Krakowskie Przedmieście 26/28, 00-927 Warsaw, Poland \\ ${ }^{3}$ Institute of Archaeology, Cardinal Stefan Wyszyński University, Wóycickiego 1/3, 01-938 Warsaw, Poland
}

\begin{abstract}
The archaeological site Tell el-Retaba in north-eastern Egypt, about $35 \mathrm{~km}$ to the west of Ismailia city, is located in the middle of Wadi Tumilat, a shallow valley running from the Nile Delta to the Bitter Lakes, along which flows the Suez Canal. In ancient times the valley was a route between Egypt and Syro-Palestine, strongly fortified in the New Kingdom times $\left(16^{\text {th }}-11^{\text {th }}\right.$ century BC). Mud bricks were analyzed from two parts of the Wall 1 (core of grey-brown bricks and inner extension of green bricks) in a fortress which existed during the Ramesses II times. Grain-size composition of the studied bricks was almost identical in both parts of the wall, suggesting the same source material for a production of brick. However, significant differences were observed in physical and mechanical properties (uni-axial compressive strength) in both types of bricks. Bricks from the core had lower bulk density, higher porosity and soak faster, whereas their resistance parameters were much lower than those of the bricks from the inner extension. The reason for such large differences in brick properties was a technology of their production, particularly proportion of components, water volume added during brick formation or density degree. Brick preparation and in consequence, physical-mechanical properties had direct influence on preservation of defensive structures during environmental changes related to changes of groundwater and surface water levels or of precipitation. Ancient Egyptians responsible for construction works in mud brick structures of the fortress must have had good knowledge and experience. This could be observed particularly for the heaviest and most important construction element that is the defensive wall, founded on well-densified deposits. It was also testified by higher resistance of green bricks from the inner extensions, which probably originated slightly later and were intended to reinforce a weaker core built of grey-brown bricks.
\end{abstract}

Key words: ancient Egypt, mud bricks, physical parameters, compressive strength.

Manuscript received 8 October 2015, accepted 12 April 2016

\section{INTRODUCTION}

Civilization of ancient Egypt has been often referred to as a stone one. This term, however, was misleading, because not a stone but mud bricks were the basic construction materials in the times of the pharaonic Egypt (Clark and Engelbach, 1930; Lacovara, 1984; Kemp, 2009). The oldest examples of mud brick architecture were from the pre-dynastic times and related to settlements in Mermida Bani Selama, Maadi, Badari and Gerza (Brunton and Caton- Thompson, 1928; Hayes, 1963; Kemp, 2009).

A low resistance of this material to humidity was insignificant due to very dry climate in Egypt. Mud bricks were used as the basic building material in housing architecture, and not rarely also for construction of temples, tombs and even pyramids. Surprisingly, despite the enormous number of mud brick structures preserved in Egypt, aspects of engi- neering characteristics of this material have not been studied in detail (Kemp, 2009). The issue is crucial, because many brick monuments underwent fast deterioration due to human activities and ongoing climate change, especially reflected by winter rainfalls. A challenge for the future will be preservation and protection of ancient mud brick monuments, not only in Egypt but also in the neighbouring Sudan. This paper begins a series of more complex investigations of geological-engineering characteristics of ancient Egyptian mud bricks, which should aid in working out a successful method of protection and conservatory revitalization of the Egyptian mud-brick architecture.

Complex studies of resistance parameters in ancient mud bricks were carried out at the Tell el-Retaba archaeological site in north-eastern Egypt, about $35 \mathrm{~km}$ to the west of Ismailia city (Fig. 1), in central part of Wadi Tumilat - a shallow valley along the eastern Nile Delta margin. The first ar- 


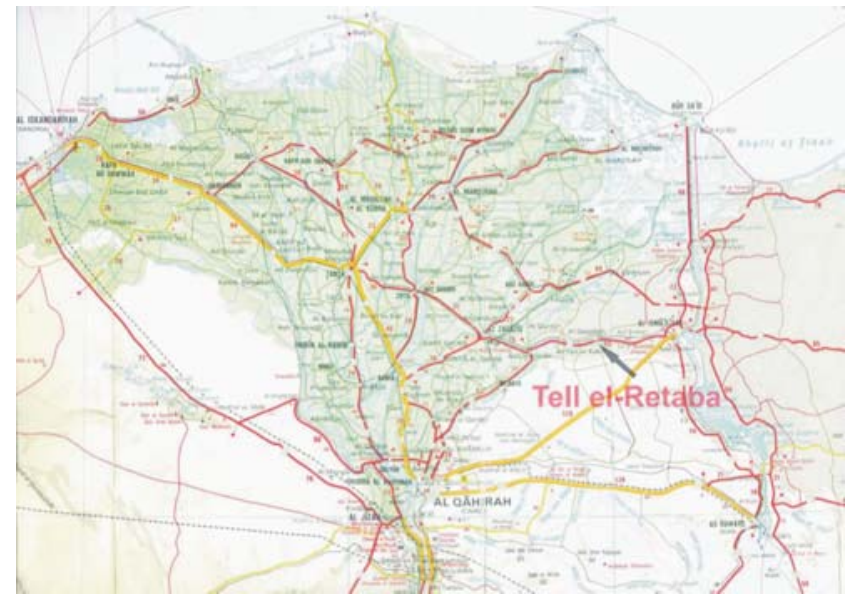

Fig. 1. Northern Egypt with location of Tell el-Retaba.

chaeological investigations at Tell el-Retaba were initiated already at the end of the $19^{\text {th }}$ century by Naville (1887). He documented huge defensive walls composed of mud bricks, which were incorrectly interpreted as remains of a Roman army camp from the first centuries A.D. At the beginning of the $20^{\text {th }}$ century, excavations at Tell el-Retaba were conducted by Petrie (Petrie and Duncan, 1906). These activities determined that brick fortifications were from the pharaonic times (Fig. 2). In the $20^{\text {th }}$ century several Egyptian and an American mission worked on the site. Since 2007, complex archaeological investigations including excavations, archae- ological, geophysical and geological prospection were conducted by the Polish-Slovak Archaeological Mission. The mission worked under the auspices of the Polish Centre of Mediterranean Archaeology of the University of Warsaw. Involved were also the Institute of Archaeology of the University of Warsaw; the Slovak Academy of Science and the Aigyptos Foundation in Bratislava (Rzepka et al., 2009, 2011, 2014, 2015).

The oldest settlement at the site was founded in the late phase of the Second Intermediate Period $\left(17^{\text {th }}-16^{\text {th }}\right.$ century $\mathrm{BC})$. A settlement still existed in the beginning of the New Kingdom (16th-15th century BC), but later the site was abandoned (Rzepka et al., 2012/2013). The settlement hiatus lasted till the beginning of the 19th dynasty (13th century BC), when a fortress was built (Górka and Rzepka, 2011), surrounded by a massive defence wall referred here to as Petrie's Wall 1 (cf. Figs 2, 3). The Wall 1 was found to be a non-uniform structure, developed in several phases (Figs 4,5 ). The fortress surrounded by the Wall 1 existed for several dozen of years. By the end of the $19^{\text {th }}$ Dynasty, defensive walls and inner constructions were in ruin. At the beginning of the $20^{\text {th }}$ Dynasty $\left(1^{\text {st }}\right.$ half of the $12^{\text {th }}$ century BC), in the Ramesses III times, the ruins were levelled and a new, larger fortress was constructed on the site. This fortress was surrounded by a much larger brick wall, referred to as the Wall 2. The fortress existed for over a hundred years. During the Third Intermediate Period, the defensive walls were already ruined and an open settlement existed at least to the Late Period (Rzepka et al., 2009, 2011, 2014, 2015).

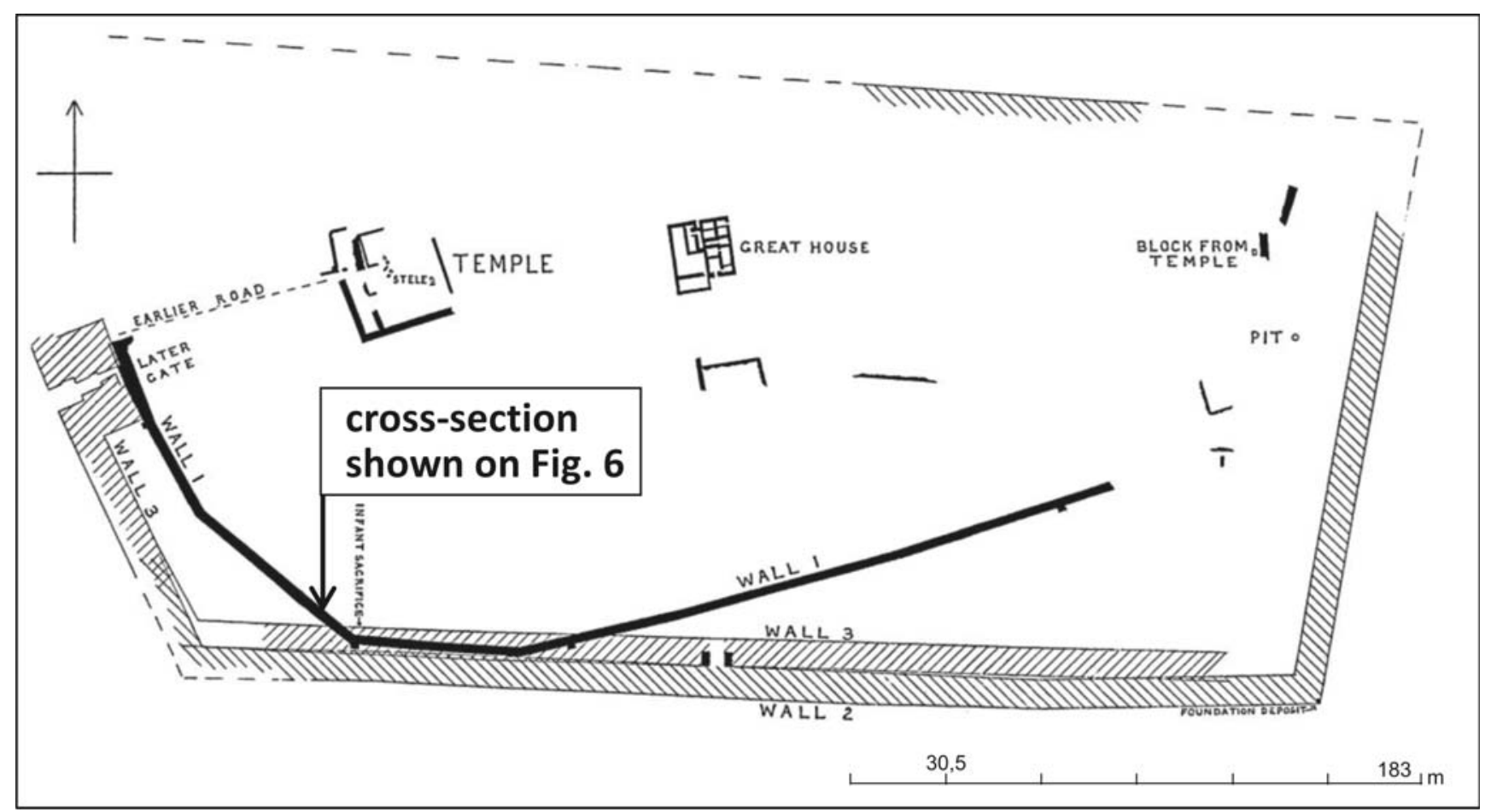

Fig. 2. Petrie's plan of Tell el-Retaba: the Wall 1 of the fortress of Ramesses II, the Wall 2 and the Wall 3 of the fortress of Ramesses III (after Petrie and Duncan, 1906) 


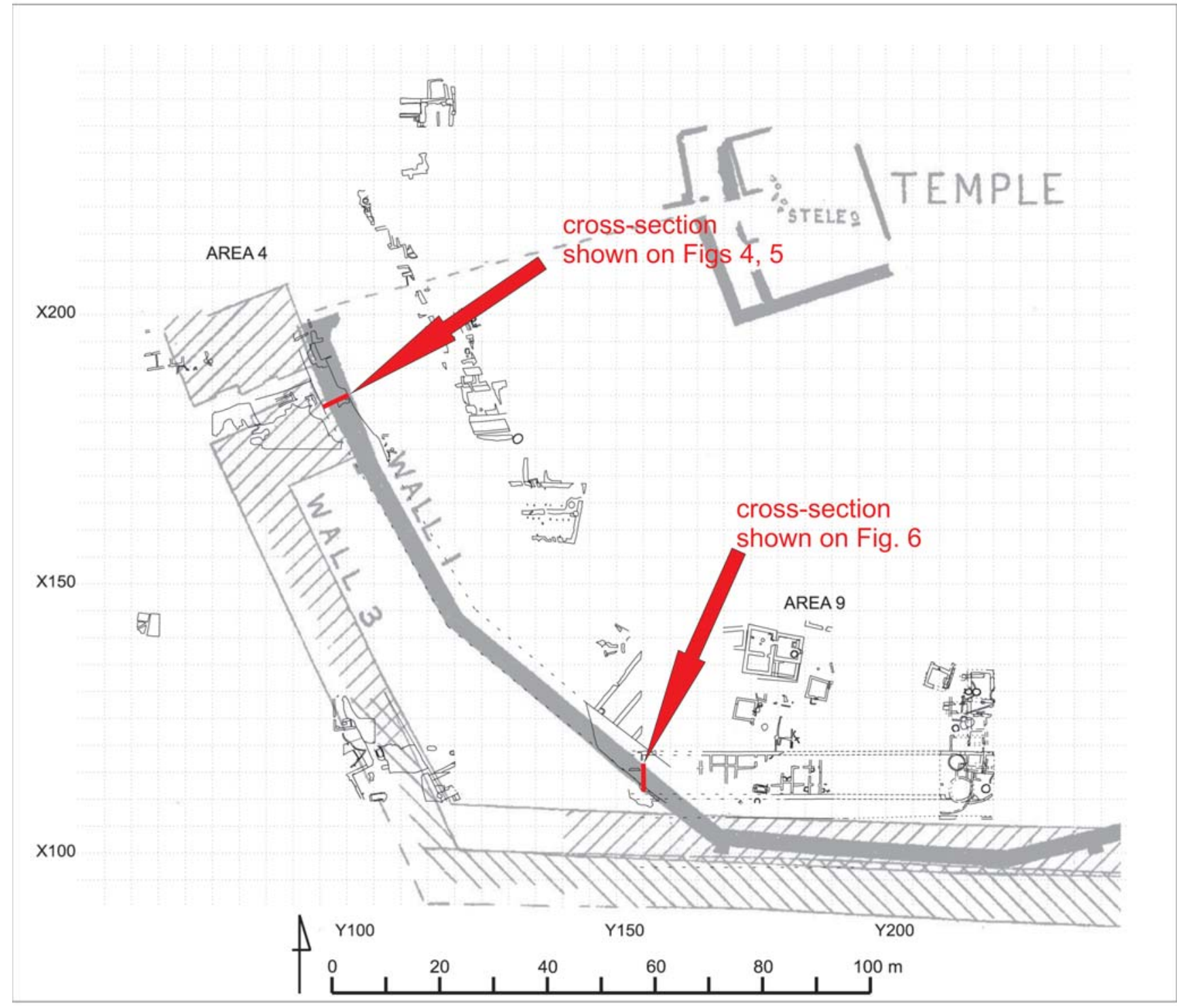

Fig. 3. Western part of the tell, excavated by the Polish-Slovak Archaeological Mission (Drawing by Ł. Jarmużek).

\section{GEOLOGICAL-ENGINEERING CONDITIONS OF SUBSTRATE AND STRUCTURE OF THE WALL 1}

The Wall 1 was built on coarse-grained grey-brown gravels (Figs 6, 7, 8), with a low content of sand and silt (Rzepka et al., 2015). A thin white cover with distinct traces of pebble dragging was noted on a hard top surface of gravels (Fig. 7). There was a medium content of $\mathrm{CaCO}_{3}$ in the white bed. Due to the uneven top surface of the gravel bed, prior to wall building, the area was levelled by a sand layer up to $17 \mathrm{~cm}$ thick. The admixture of calcium carbonate could have caused better stabilization of a substrate and its binding with the sand ballast. Directly adjacent to the white layer, the sand had a low content of $\mathrm{CaCO}_{3}$.

The Wall 1 was composed of a core of grey-brown bricks up to $2 \mathrm{~m}$ wide (cf. Fig. 5). The whole wall was about $6 \mathrm{~m}$ wide (Figs 6, 8). The bricks had small content of $\mathrm{CaCO}_{3}$. Grain size composition was predominated by fine fraction, $0.1-1.0 \mathrm{~mm}$ in diameter, with admixture of gravels $(2-20 \mathrm{~mm})$ and a low content of silt and clay. Sometimes, fragments of ceramic were used instead of a gravel in bricks of the wall core.

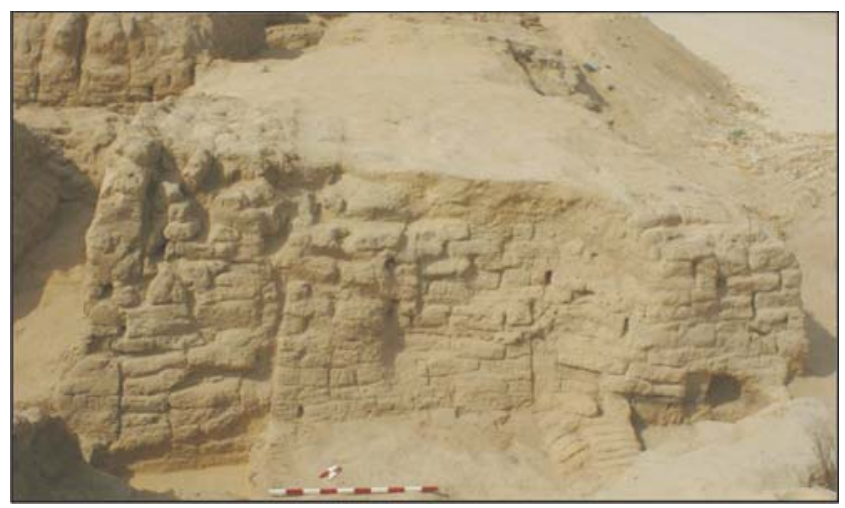

Fig. 4. Section through the Wall 1 in the area 4 (Photo by J. Hudec). 


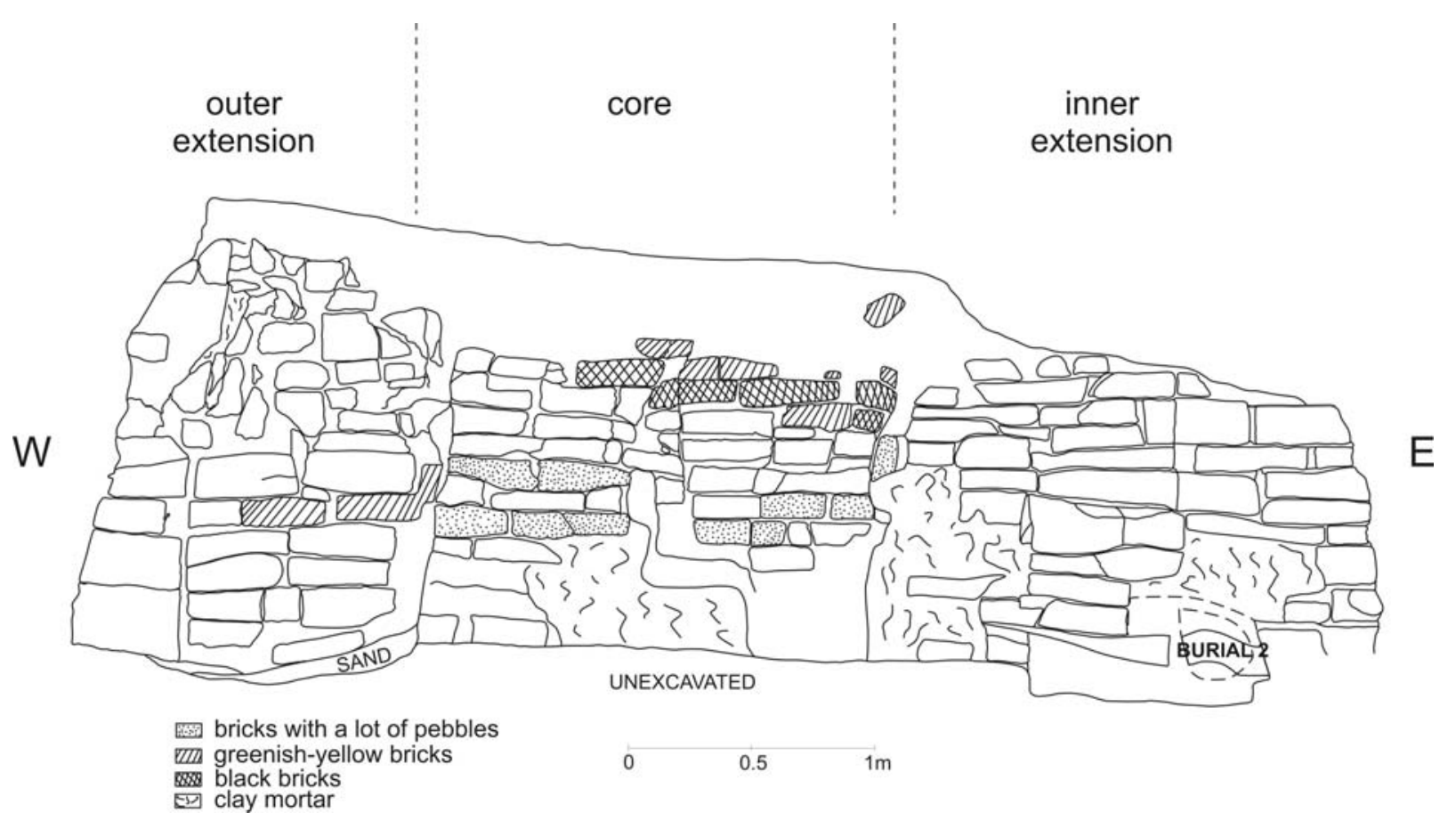

Fig. 5. Section through the Wall 1 in the area 4 (Drawing by K. Górka and Ł. Jarmużek).

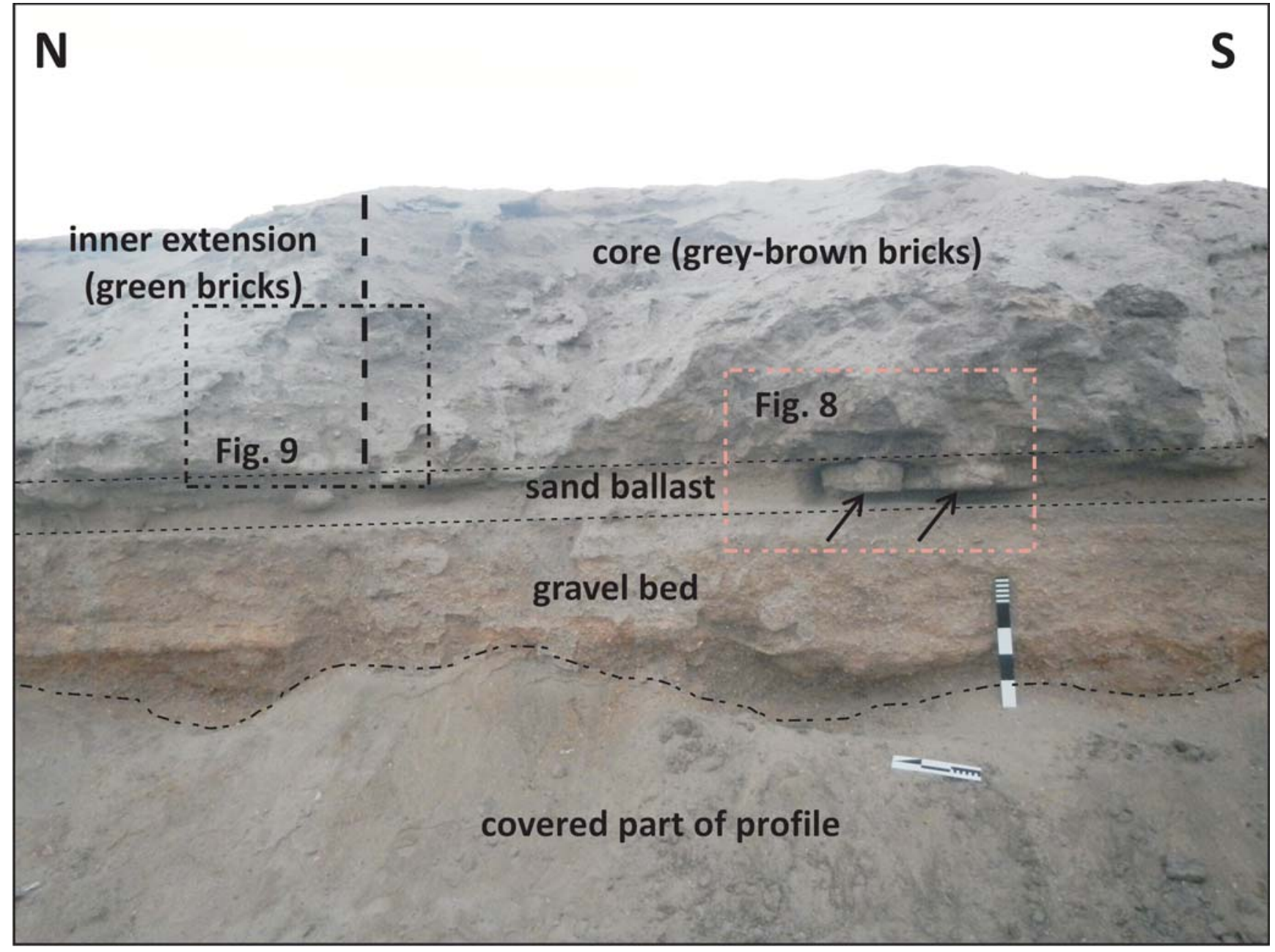

Fig. 6. Exposure of the Wall 1 in the area 9. Dashed-line rectangles denote fragments of the Wall 1 with grey-brown bricks (Fig. 8) and with green bricks (Fig. 9). Arrows point to bricks in sand ballast. 


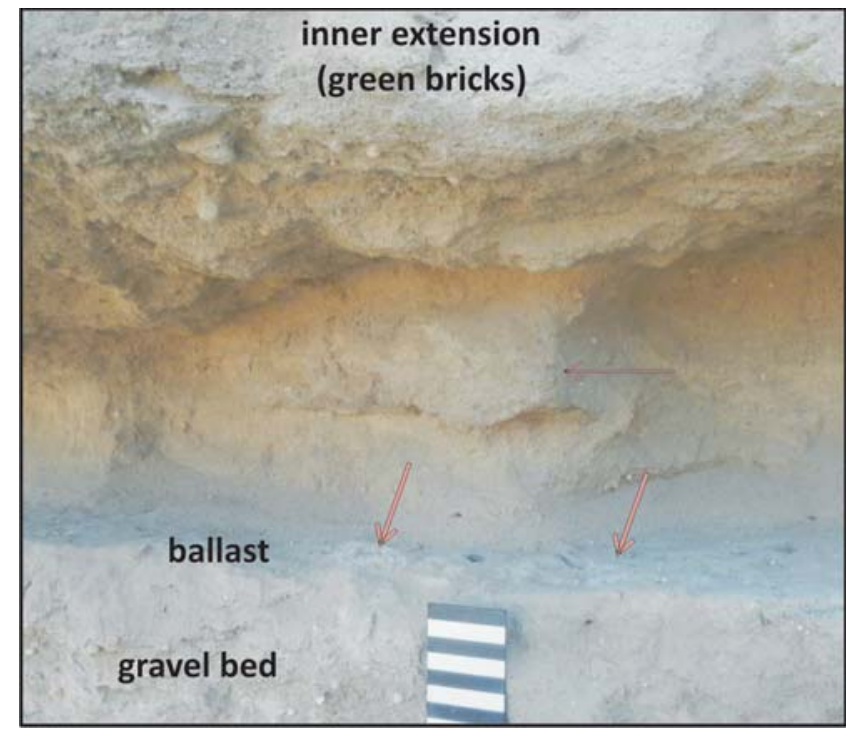

Fig. 7. Gravel bed with white layer, which covers a top surface (marked with bold arrows). Brick visible in ballast (marked with a thin arrow).

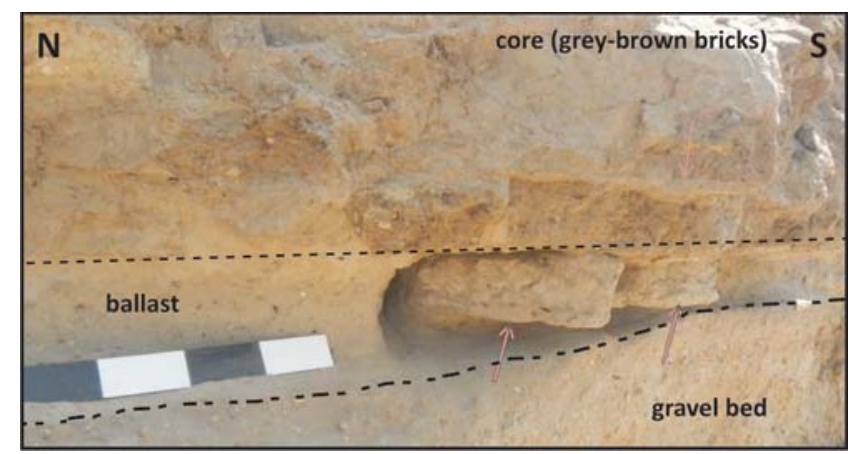

Fig. 8. Fragment of the Wall 1: a core with grey-brown bricks (cf. Fig. 6), note poorly preserved bricks and their primary arrangement. Light grey mortar is between the bricks (marked with a thin arrow). Bold arrows point to bricks in the sand ballast (as in Fig. 6).

Light-grey mortar was preserved between the bricks (Fig. 8), composed mainly of sand, mixed with clay and fine gravel (diameter $5 \mathrm{~mm}$ ). This material contained much $\mathrm{CaCO}_{3}$. In places, the mortar contained more sand and thus was less cohesive, in turn the clay-silty mortar was harder and more cohesive. During the construction of the wall core, the bricks were bound (cf. Fig. 9).

The inner extension directly adhered to the core and it was composed of green mud bricks (Figs 6, 9). The bricks comprised mainly fine fractions (diameter $0.1-1.0 \mathrm{~mm}$ ) and some gravels $(2-20 \mathrm{~mm}$. There was a medium content of $\mathrm{CaCO}_{3}$. A light grey mortar with admixture of clay and fine gravel $(5 \mathrm{~mm})$ occurred between the bricks. Fine fraction, about $0.1 \mathrm{~mm}$, prevailed. There was a larger content of $\mathrm{CaCO}_{3}$ than in the bricks. Green bricks were bound similarly as the grey-brown ones, but their preservation was better in comparison to bricks of the wall core (Fig. 9).

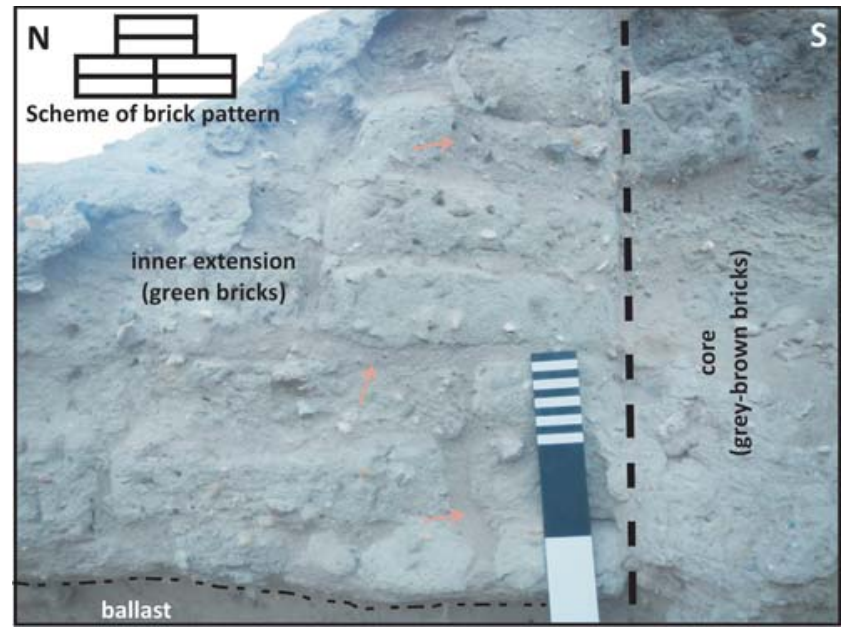

Fig. 9. Fragment of the Wall 1 (cf. Fig. 6). Note well-preserved bricks and their primary arrangement in the inner extension, light grey mortar is between the bricks (marked with arrows). Bonding pattern in the upper left corner is visible at the photo.

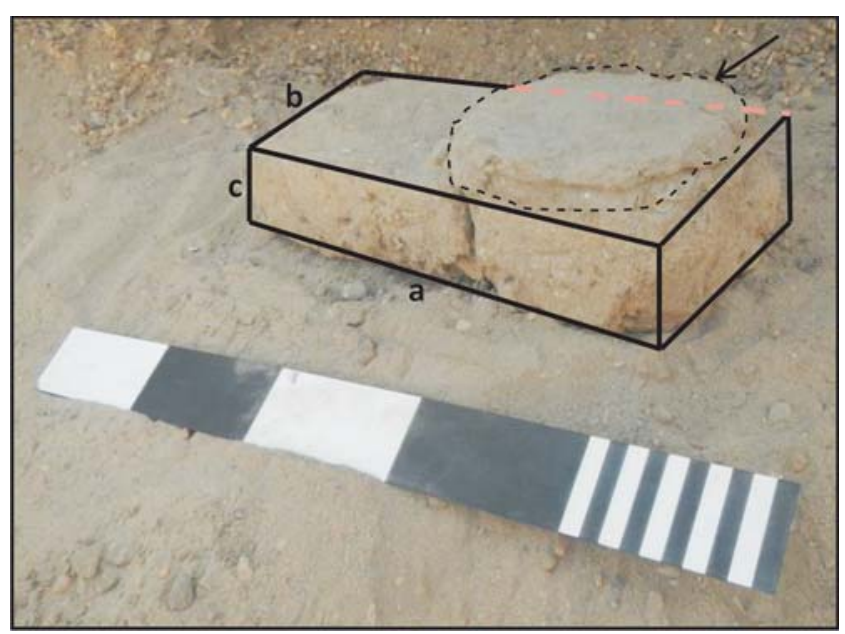

Fig. 10. Grey-brown brick from the Wall 1 with fragmentarily preserved mortar on the upper surface (marked with an arrow and outlined with a thin dashed line). Brick dimensions: length $a$, width $b$ and height $c$ (see text for details).

\section{METHODOLOGY}

Studies of the materials concerning physical and mechanical properties of bricks at the Tell el-Retaba archaeological site were focused on the exposed part of the Wall 1 , which was preserved in the western part of the site (Rzepka et al., 2015). Geological-engineering analyses of bricks of the Wall 1 were conducted in September 2015. During field works, a broad documentation of the exposed wall fragments was done, including lithology of the substrate and brick dimensions. Small cuboid brick samples (4-8 cm long, 5-7 cm wide and 4-6 $\mathrm{cm}$ high) with parallel upper and lower surfaces were cut out for laboratory analyses and strength tests. A bulk density of the samples was determined using a classical pycnometer. To determine this parameter the material was collected from about $1 \mathrm{~kg}$ samples. Measurements of bulk 


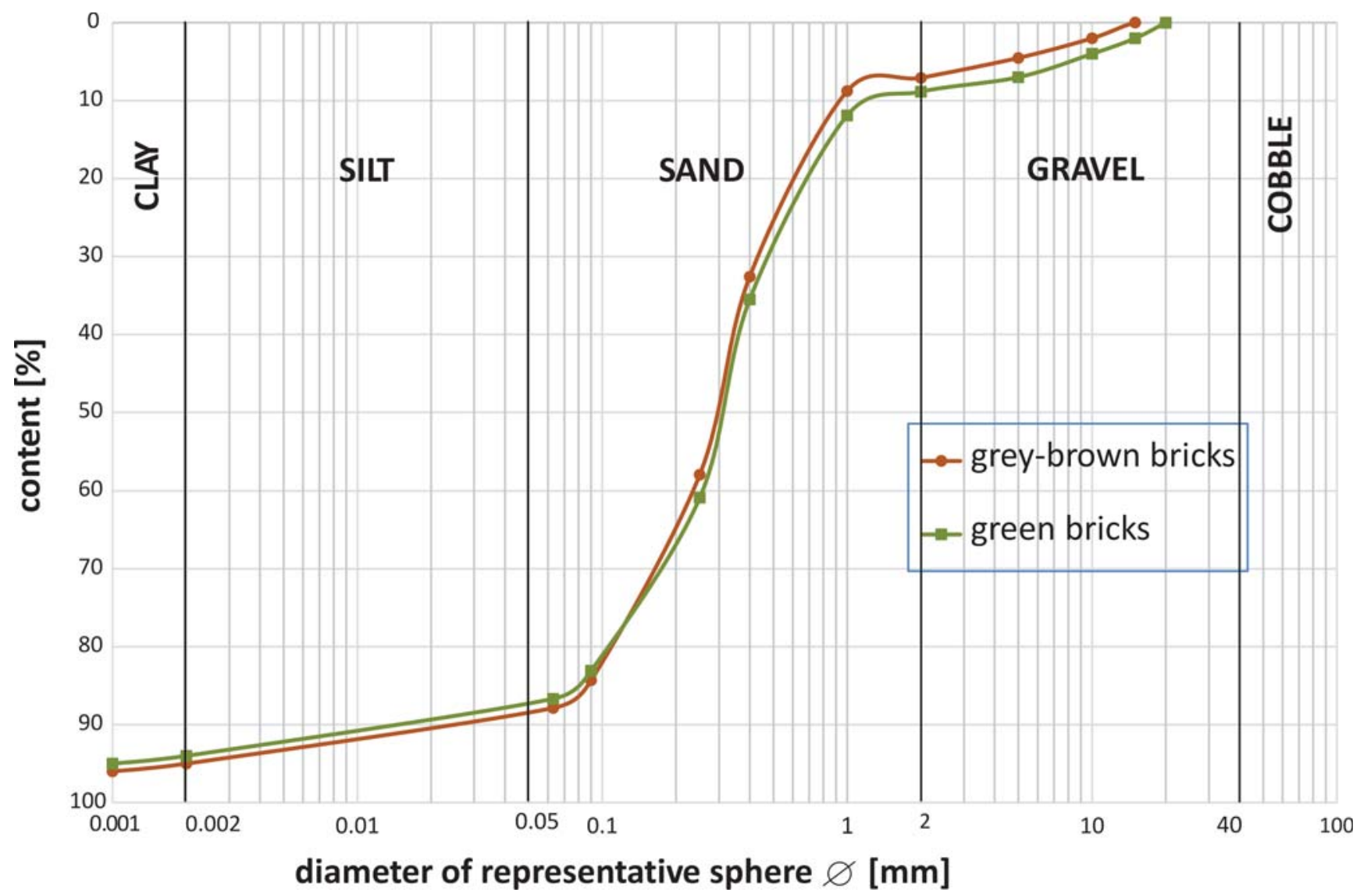

Fig. 11. Grain size composition for bricks from the Wall 1; archaeological site at Tell el-Retaba, Egypt.

density were done with the buoyancy method. The samples were $4-8 \mathrm{~cm}^{3}$ in volume. The samples were soaked in distilled water on a net with mesh size $1 \times 1 \mathrm{~cm}$ and the time was measured when the whole sample was broken down. Soaking was determined on samples about $30 \mathrm{~cm}^{3}$ in volume.
For grain size analysis, the samples were subjected to preliminary subdivision into coarse and fine fractions due to a low contribution of silt and clay, and high contribution of sand and gravel in bricks. Fractions $>0.05 \mathrm{~mm}$ were selected for sieve analysis, whereas fractions $<0.05 \mathrm{~mm}$ were sub-

Table 1

Results of grain size composition analysis of bricks from the Wall 1, archaeological site at Tell al-Retaba, Egypt

\begin{tabular}{|c|c|c|c|c|}
\hline \multirow{2}{*}{$\begin{array}{l}\text { Sample collection site } \\
\text { from "Wall 1" }\end{array}$} & \multicolumn{4}{|c|}{ Grain size fraction $f[\%]$} \\
\hline & $\begin{array}{c}\text { gravel } \\
40>\phi>2 \mathrm{~mm}\end{array}$ & $\begin{array}{c}\text { sand } \\
2>\phi>0.05 \mathrm{~mm}\end{array}$ & $\begin{array}{c}\text { silt } \\
0.05>\phi>0.002 \mathrm{~mm}\end{array}$ & $\begin{array}{c}\text { clay } \\
\phi<0.002 \mathrm{~mm}\end{array}$ \\
\hline Core - grey-brown bricks & 7 & 81 & 7 & 5 \\
\hline $\begin{array}{l}\text { Inner extension - green } \\
\text { bricks }\end{array}$ & 9 & 78 & 7 & 6 \\
\hline
\end{tabular}


Table 2

Results of physical and mechanical properties of bricks from the Wall 1, archaeological site at Tell el-Retaba, Egypt

\begin{tabular}{|c|c|c|c|c|c|c|c|c|c|c|c|c|}
\hline \multirow{2}{*}{$\begin{array}{l}\text { Sample } \\
\text { collection } \\
\text { site from } \\
\text { "Wall 1" }\end{array}$} & \multicolumn{6}{|c|}{ Physical properties } & \multicolumn{3}{|c|}{ Soaking } & \multicolumn{3}{|c|}{ Mechanical protperties } \\
\hline & $\begin{array}{c}\text { Specific } \\
\text { density } \\
\rho_{s}\left[\mathrm{Mg} / \mathrm{m}^{3}\right]\end{array}$ & $\begin{array}{c}\begin{array}{c}\text { Number } \\
\text { of } \\
\text { samples }\end{array}\end{array}$ & & $\begin{array}{l}\text { Bulk density } \\
\rho_{d}\left[\mathrm{Mg} / \mathrm{m}^{3}\right]\end{array}$ & $\begin{array}{c}\text { Bult density at } \\
\text { complete pore } \\
\text { saturation with water } \\
\rho_{\mathrm{sr}}\left[\mathrm{Mg} / \mathrm{m}^{3}\right]\end{array}$ & $\begin{array}{c}\text { Porosity } \\
n[\%]\end{array}$ & $\begin{array}{c}\text { Number } \\
\text { of } \\
\text { samples }\end{array}$ & & $\begin{array}{l}\text { Soaking } \\
\text { time } t[s]\end{array}$ & $\begin{array}{c}\text { Number } \\
\text { of } \\
\text { samples }\end{array}$ & & $\begin{array}{l}\text { Uniaxial compressive } \\
\text { strength } R_{c}[\mathrm{kPa}]\end{array}$ \\
\hline \multirow{4}{*}{$\begin{array}{l}\text { Core - grey- } \\
\text { brown } \\
\text { bricks }\end{array}$} & \multirow{4}{*}{2.60} & \multirow{4}{*}{8} & $\mathbf{R}$ & $1.49-1.84$ & $1.92-2.13$ & $29.23-42.69$ & \multirow{4}{*}{4} & $\mathbf{R}$ & $5.0-9.8$ & \multirow{4}{*}{13} & $\mathbf{R}$ & $28.4-132.3$ \\
\hline & & & $\overline{\mathbf{x}}$ & 1.68 & 2.03 & 35.48 & & $\overline{\mathbf{X}}$ & 6.8 & & $\overline{\mathbf{X}}$ & 93.3 \\
\hline & & & $\sigma$ & 0.12 & 0.07 & 4.49 & & $\sigma$ & 1.87 & & $\sigma$ & 26.9 \\
\hline & & & $v$ & 6.95 & 3.54 & 12.64 & & $v$ & 27.5 & & $v$ & 29 \\
\hline \multirow{4}{*}{$\begin{array}{l}\text { Inner } \\
\text { extension- } \\
\text { green bricks }\end{array}$} & \multirow{4}{*}{2.64} & \multirow{4}{*}{10} & $\mathbf{R}$ & $1.67-1.81$ & $2.01-2.10$ & $31.44-36.74$ & \multirow{4}{*}{5} & $\mathbf{R}$ & $8.5-16.8$ & \multirow{4}{*}{11} & $\mathbf{R}$ & $41.5-336.5$ \\
\hline & & & $\overline{\mathbf{X}}$ & 1.75 & 2.08 & 33.71 & & $\overline{\mathbf{X}}$ & 12.9 & & $\overline{\mathbf{X}}$ & 152.7 \\
\hline & & & $\sigma$ & 0.05 & 0.03 & 1.76 & & $\sigma$ & 2.83 & & $\sigma$ & 92.7 \\
\hline & & & $v$ & 2.67 & 1.39 & 5.21 & & $v$ & 21.94 & & $v$ & 61 \\
\hline
\end{tabular}

Explanations: R-range of variability; $\min$ - $\max , \overline{\mathbf{X}}$ - arithmetic mean, $\boldsymbol{\sigma}$ - standard deviation, $\mathbf{v}$ - variability index

jected to sedimentation analysis. Accordingly, the brick samples were washed with distilled water on a sieve with mesh diameter of $0.05 \mathrm{~mm}$. To determine weight of clay and silt, a suspension with these fractions was subjected to decantation. After decantation, the sediment was dried and weighed. Based on the determined parameters, porosity and bulk density at complete pore saturation were calculated. The investigations were conducted according to the norm (PN-88/B04481) and soaking was determined according to the methodology of Kaczyński (1981).

Strength to uni-axial compression was supposed to be measured on cylinder samples. Cutting out of such samples was impossible due to non-uniform grain size composition in the examined material and equipment limitations. Such conditions constrained unconfined compression with irregular samples. The cut-out samples were cuboid and investigations were conducted in a modified uni-axial compression procedure. The modification admitted variable sample proportions and dimensions. This step allowed adapting to varied grain size composition of the examined material and the natural cuboid shape of bricks. The investigations were conducted according to standard (PKN-CEN ISO/TS 17892-7, 2004).

\section{PHYSICAL-MECHANICAL PROPERTIES OF MUD BRICKS FROM TELL EL-RETABA}

Dimensions of the mud bricks from the Wall 1 were measured. Minimum, maximum and average length (dimension $a$ in Fig. 10) of grey-brown bricks (36-38 cm, $37 \mathrm{~cm})$ was slightly larger than a respective length of green bricks (34$36 \mathrm{~cm}, 35 \mathrm{~cm}$ ). Higher variability of minimum and maximum values was observed with regard to width (dimension $b$ in
Fig. 10) of bricks. The width of grey-brown bricks was 15$17 \mathrm{~cm}$, and $14-19 \mathrm{~cm}$ of green bricks. The average value of dimension $b$ did not indicate large discrepancies and was 16 $\mathrm{cm}$ for grey-brown bricks and $17 \mathrm{~cm}$ for green bricks. Similarly as in the case of the width, a height (dimension $c$ in Fig. 10) was characterized by larger variability of minimum, maximum and average values. The height of grey-brown bricks was between $6-8 \mathrm{~cm}$ (average $7 \mathrm{~cm}$ ), whereas for green bricks it was $7-10 \mathrm{~cm}$ (average $9 \mathrm{~cm}$ ). Small differ-

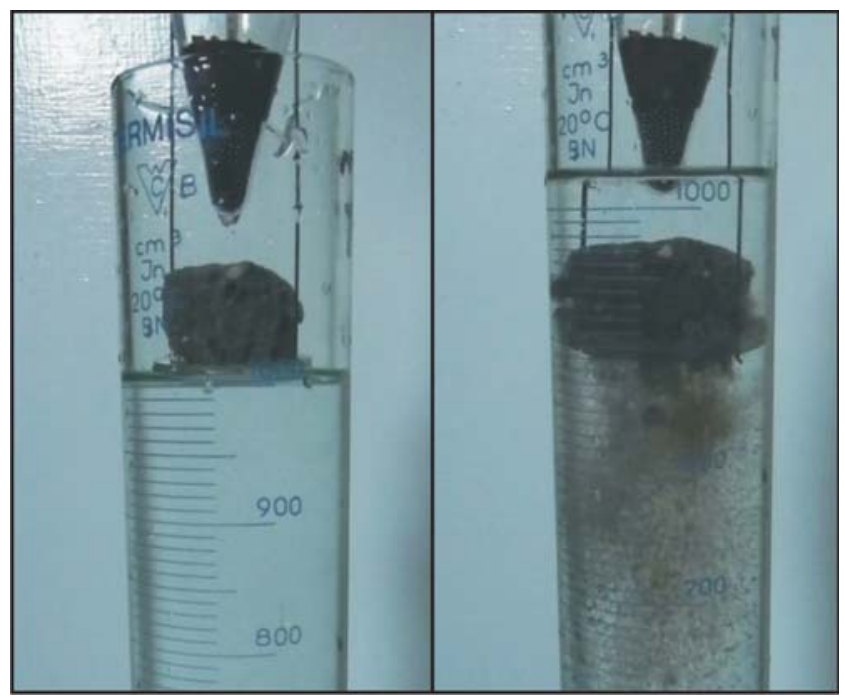

Fig. 12. Soaking of a grey-brown brick: left photograph - sample prior to inserting in water, right photograph - desintegration of a sample after inserting in water. 
ences in dimensions between grey-brown and green bricks indicated that production of both brick types was similar and forms used for their production were unified.

Grain size content in bricks from both parts of the Wall 1 was very similar (Table 1, Fig. 11). Small differences occurred in gravel, sand and clay (1-3\%). Bulk density was varied insignificantly: $2.60 \mathrm{Mg} / \mathrm{m}^{3}$ for grey-brown and 2.64 $\mathrm{Mg} / \mathrm{m}^{3}$ for green bricks (Table 2). Analysis of a bulk density indicated that this parameter was varied with regard to higher minimum and maximum values for grey-brown than for green bricks. Such relationship was also common in case of porosity. The average value of bulk density for grey-brown bricks $\left(1.68 \mathrm{Mg} / \mathrm{m}^{3}\right)$ implied higher average porosity $(35.4 \%)$. Parameters of green bricks were characterized by opposite relationship and average values for both parameters were 1.75 $\mathrm{Mg} / \mathrm{m}^{3}$ and $33.7 \%$, respectively. In order to determine filtration properties and ability to retain water, a bulk density of bricks was measured at complete water saturation of pores. Analysis of this parameter indicated that grey-brown bricks had more variable minimum and maximum values than green bricks.

In order to determine a susceptibility of bricks to humidity changes and absorbability, their soaking properties were tested (Fig. 12, Table 2). It was found that minimum and maximum soaking times were longer for green than for grey-brown bricks. An average soaking time for green bricks $(12.9 \mathrm{~s})$ was almost twice longer than for grey-brown bricks $(6.8 \mathrm{~s})$.

Both grey-brown and green bricks were characterized by high variability of minimum and maximum values of uni-axial compression strength (Table 2). In the case of green bricks, maximum values were almost three times higher than for grey-brown bricks. Despite such large differences, the average value of this parameter was not as high for green bricks $(152.7 \mathrm{kPa})$ in relation to grey-brown bricks $(93.3 \mathrm{kPa})$. The uni-axial compression strength tests were conducted on 13 samples of grey-brown and 11 samples of green bricks (Table 2). Despite a large dispersion of minimum and maximum values, statistical analysis indicated that grey-brown bricks were characterized by larger uniformity (variability index 29) in comparison to green bricks (variability index 61). A similar situation was in case of standard deviation. The strength of samples of grey-brown bricks was much closer to the average value in the tests (standard deviation at 26.9) than for the green bricks (standard deviation at 92.7). Despite the fact that differences in average strength values for both types of bricks were not significant, a higher variability was observed in the green bricks.

Determination of bulk density, bulk density at complete pore saturation with water, and porosity was done for 8 samples of grey-brown bricks and 10 samples of green bricks (Table 2). Despite the fact that grey-brown bricks indicated larger differences in minimum and maximum values than green bricks, the average bulk density for both types did not differ significantly and was $1.68 \mathrm{Mg} / \mathrm{m}^{3}$ and $1.75 \mathrm{Mg} / \mathrm{m}^{3}$, respectively. A standard deviation for particular parameters was similar for both brick types: for grey-brown bricks standard deviation of bulk density was 0.12 , for bulk density at complete pore saturation with water -0.07 and for porosity 4.49. For green bricks the values were $0.05,0.03$ and 0.02 , re- spectively. These values were almost two times lower for green bricks. A similar observation was done when analysing variability indexes of all physical parameters. The values of this parameter for green bricks $(2.67,1.39$ and 5.21 respectively: Table 2) were two times lower than for grey-brown bricks (6.95, 3.54 and 12.64 respectively: Table 2). Green bricks were characterized by larger uniformity of physical parameters than grey-brown bricks.

Despite the larger uniformity of physical parameters, green bricks indicated larger variability of their uni-axial compressive strength in comparison to grey-brown bricks.

\section{INFLUENCE OF ENVIRONMENTAL CONDITIONS ON ENGINEERING PROPERTIES OF BRICKS FROM THE WALL 1}

It is obvious that the location of the Wall 1 was selected appropriately. Gravel sediments described above formed the highest ground in the area of the planned fortress. These sediments represented also a well-densified (hardened) substrate (Rzepka et al., 2015). They were thus a natural foundation for construction of a wide and high wall. To compare, similar beds of redeposited gravels were used as foundation for a monumental wall surrounding the oldest Egyptian pyramid, constructed during the Old Kingdom (about 2,600 BC) by Pharaoh Netjerykhet in Sakkara (Welc and Trzciński, 2013).

Another issue that influenced stabilization of a contact zone between the substrate and the wall foundations was covering a gravel top by a sandy layer that levelled all irregularities. This layer acted also as an easily densifying substrate for the first, lowermost layer of dry and stiff bricks. The sandy layer caused that subsequent brick layers that generated increasing stress on the substrate, had not been cracked. Additionally, better binding of a sand layer with the substrate was achieved by covering the gravel top with a binding calcareous layer. The sand that acted as the ballast was well-sorted sediment, which pointed out its earlier selection (sieving), most probably using the existing resources.

A variable preservation state of the core and inner extension of the Wall 1, particularly between lower and upper parts of the wall, could indicate water seeping during high level of the Nile. In effect of water fluctuation, the water table has changed in the reservoir directly to the north of the fortress (Rzepka et al., 2015). Periodical rise of the groundwater level resulted in dampening of the lower part of the wall and in brick deformations. Most probably, due to this reason the primary wall (core) was reinforced by adding external brick layers, forming an extension both on inner and outer sides.

Similar grain size composition (Fig. 11, Table 1) of grey-brown and green bricks suggested that the material for their production came from the same source. Small differences of $1-3 \%$ in contents of gravel, sand and clay could be caused by using the same material but in different proportions. The material for brick production must have come from a close vicinity of the fortress. There were most probably three types of sediments from the substrate nearby, including Pleistocene gravels, the so-called gezira sand and Holocene lake clays (cf. Rzepka et al., 2015). Local gravels constituted a significant part of the gravel fraction in both types of bricks. A similar case was with the sand fraction, in 
which the gezira sand had a large contribution. In turn, clay and silt was added to the bricks from the lake deposits located to the north of the fortress.

Wide range of bulk density values both for grey-brown and green bricks (Table 2) could be caused by non-complying with the technological regime during brick production. The source material, from which the bricks were formed, must have been poorly disintegrated (particularly silty-clayey material) and mixed. This fact was exemplified by numerous clay lumps in bricks, which were dried-up fragments of poorly disintegrated lake deposits. Higher bulk density in green bricks could result from a lower amount of water used for their production. Consequently, bricks displayed a lower porosity. Most probably, a volume of water was adjusted to assure that bricks would not undergo significant deformations after removing a form from a brick.

A soaking time was very short for both types of bricks (Table 2, Fig. 12). Such fast soaking was related to a high content of sand and high porosity values. Slight differences in soaking time between grey-brown and green bricks were probably caused by differences in mineral composition of a clay fraction and stronger bonds between the grains.

Large differences in minimum and maximum values of uni-axial compressive strength for grey-brown and green bricks were related to heterogeneity of a brick material. In the case of green bricks, where the strength was much higher than in the case of grey-brown bricks, presence of lumps of clay material was not observed. This points out to better disintegration of silty-clayey material that influenced higher uniformity and isotropic character of green bricks, and thus higher resistance values.

\section{DISCUSSION AND CONCLUSIONS}

It was commonly assumed that ancient Egyptian mud bricks contained four main components: coarse-grained sand, fine-grained sand, silt and clay, but a lack of any of these components was not an obstacle in brick production, influencing only changes of engineering parameters of such material (Kemp, 2009). Obviously, the ancient brick producers did not use any accepted norms and it resulted in large differences in lithological composition of bricks. Local conditions were of large significance, including availability of natural material, particularly sand at appropriate fraction and the binder i.e. clay and silt. The material was usually collected in the construction site facility, resulting in large differences in brick composition, even within the same locality. These differences were even more evident when comparison was done between bricks produced on the Nile floodplain and the area adjacent to the desert (Kemp, 2009). On the Nile floodplain the mud formed during floods was the material that was almost ready for brick production. In turn, in the area adjacent to the desert, where the substrate was built of limestone, the so-called tafl bricks were produced with a high contribution of very fine fractions and a calcareous binder (cf. Welc and Trzciński, 2013).

A good example is a comparison of the grain size composition of bricks from two archaeological sites in Upper Egypt, e.g. Karnak and Tell el-Amarna (French, 1981, 1984). The first site is located within the kom, a hill located on the
Nile floodplain, formed by successive settlements during several thousands years. Tell el-Amarna was a site located on the desert, at a certain distance from the Nile valley. Analysis of grain size composition of bricks from both sites was based on distinguishing three main fractions in fine and very fine sands, silt and clay. Bricks from Karnak selected for the analysis were from the archaeological contexts dated from the second millennium $\mathrm{BC}$ to the late centuries $\mathrm{BC} / \mathrm{AD}$, with addition of modern material. The bricks from Tell el-Amarna were dated at the New Kingdom, about 1,350 years BC. Based on French $(1981,1984)$, comparison of grain size composition of mud bricks from Tell el-Amarna and Karnak has revealed significant differences (Table 3). The basic difference results from the content of a binder, i.e. the finest fraction (clay). Its content in bricks from Tell el-Amarna is almost 10 times higher than in bricks from Karnak. A smaller difference was marked in contents of silt as it was lower in bricks from Tell el-Amarna by over a dozen percent. In turn, a content of sand was very similar in bricks from both sites. A separate issue was a large variability within the same fractions at both sites. Comparison of results from these sites with the results from Tell el-Retaba (Tables 1, 3) has indicated significant differences in contents of particular fractions. In bricks from Tell el-Retaba there was a very low content of silt, almost 10 times less than in bricks from Tell el-Amarna and Karnak. The second significant difference was a content of the coarsest fraction (gravel). The bricks from Tell el-Amarna and Karnak were devoid of gravel and the bricks from Tell el-Retaba contained almost $10 \%$ of gravel. The content of sand was similar in bricks from these three sites.

Comparison of results of grain size composition in bricks from the archaeological sites described above and their distinct differences (Table 3) led to a basic conclusion. The bricks from Tell el-Amarna and Karnak were produced from a material with high contribution of silt, which occurred both on floodplains and at the boundary between the desert and the limestone plateau. Silt was the main binder of bricks. Such content of silt was not noted in local sediments occurring around the Tell el-Retaba fortress. In turn, high contribution of gravel occurred in bricks from Tell el-Retaba only; it was derived from Pleistocene gravel and sand.

Contents of four basic fractions must have had large significance for preservation of this material at contact with water. Even the bricks from Tell el-Amarna and Karnak with a high contribution of silt would not be water-resistant, because the fraction ensured cohesiveness in dry material, but lost its properties at contact with water and soaked very fast. Higher resistance to water could be ensured by high contribution of clay only, which could withstand fast soaking for a longer time. Such bricks occurred only at Tell el-Amarna and they contained about $20 \%$ of clay. The bricks from Karnak could be the weakest due to the lowest content of clay.

The conducted investigations and their continuation could have crucial significance for preservation of deteriorating monuments of ancient Egypt and mud brick constructions. Extending the investigations onto aspects related to their conservation allowed finding simple solutions, protecting such monuments against influence of external factors in the future. 
The investigations conducted at the Tell el-Retaba archaeological site, focused on mud bricks from the Wall 1 of the fortress working during the Ramesses II times $\left(19^{\text {th }}\right.$ Dynasty, $13^{\text {th }}$ century $\mathrm{BC}$ ), allowed to draw the following conclusions:

- selection of a location of a wall founded on very dense sediments (gravels) coupled with area levelling and its covering with a sandy layer, on which the wall bricks were placed directly, indicated deliberate preparatory activities prior to wall construction;

- investigated part of the Wall 1 was composed of two parts: a core built of grey-brown bricks and an inner extension composed of green bricks; both types of bricks had similar dimensions and were arranged in a deliberate manner forming a wall construction;

- almost identical grain size composition of grey-brown and green bricks indicated that the same material of local origin was used for brick production: Pleistocene sand and gravel and Holocene clay-silt lake deposits;

- high contribution of coarse fractions (gravel and sand) in both types of bricks and technology of their production resulting in high porosity and low resistance have caused that bricks at contact with water underwent soaking very fast;

- poor condition of the wall construction made of grey-brown and green bricks resulted from their poor physical and mechanical parameters and was caused by sensitivity to humidity changes, e.g. oscillations of groundwater level or periodical rainfall.

\section{Acknowledgements}

The research was supported by the Polish National Science Centre (grant 2012/05/B/HS3/03748) and the Slovak Research and Development Agency (grant APVV-5970/12).

\section{REFERENCES}

Brunton, G., Caton-Thompson, G., 1928. The Badarian Civilisation and Predynastic Remains Near Badari. London, BSAE.

Clarke, S., Engelbach, R., 1930. Ancient Egyptian construction and architecture. New York.

French, C.A.I., 1981. An analysis of the sediment at East Karnak. JSSEA, 11: 78-263.

French, C.A.I., 1984. A sediments analysis of the mud brick and natural features at El Amarna. In: B.J. Kemp (Ed.), Amarna Reports I,. London, EES, 189 - 202.

Górka, K., Rzepka, S., 2011. Infant burials or infant sacrifices?
New Discoveries from Tell el-Retaba. Mitteilungen des Deutschen Archäologischen Instituts Kairo 67, 93-100.

Hayes, W.C., 1965. Most Ancient Egypt. Chicago and London. Univ. Chicago Press.

Kaczyński, R., 1981. The strength and deformability of the Upper Miocene clays Foredeep (Wytrzymałość i odkształcalność górno mioceńskich iłów zapadliska przedkarpackiego). Biuletyn Geologiczny Wydziału Geologii UW, 29, 105-193.

Kemp, B., 2009. Soil (including mud - brick architecture). In: P.T. Nicholson, I. Shaw (Eds), Ancient Egyptian Materials and technology. Cambridge.

Lacovara, P., 1984. Archaeology and the decay of mudbrick structures in Egypt I. NARCE 128, 20-21.

Naville, E., 1887. The shrine of Saft-El-Henneh and the Land of Goshen. Egypt Exploration Fund Memoir 5, London.

Petrie, W.M.F., Duncan, J.G., 1906. Hyksos and Israelite Cities. British School of Archaeology in Egypt 12, London.

PKN-CEN ISO/TS 17892-7, 2004. Badania geotechniczne. Badania laboratoryjne gruntów, 7: Badanie na ściskanie gruntów drobnoziarnistych w jednoosiowym stanie naprężenia. PKN, Warszawa.

PN-88/B-04481. Grunty budowlane. Badania próbek gruntu.

Rzepka, S., Wodzińska, A., Hudec, J., Herbich, T., 2009. Tell el-Retaba 2007-2008. Ägypten and Levante 19, 241-280.

Rzepka, S., Wodzińska, A., Malleson, C., Hudec, J., Jarmużek, Ł., Misiewicz, K., Małkowski, W., Bogacki, M., 2011. New Kingdom and the Third Intermediate Period in Tell el-Retaba. Results of the Polish-Slovak Archaeological Mission, Seasons 2009-2010. Ägypten and Levante 21, 139-184.

Rzepka, S., Nour el-Din, M., Wodzińska, A., Jarmużek, Ł., 2012/ 2013. Egyptian Mission Rescue Excavations in Tell el-Retaba, 1: New Kingdom Remains. Ägypten and Levante 22/23, 253-288.

Rzepka, S., Hudec, J., Wodzińska, A., Jarmużek, Ł., Hulková, L., Dubcová, V., Piorun, M., Šefćáková, A., 2014. Tell el-Retaba from the Second Intermediate Period till the Late Period. Results of the Polish-Slovak Archaeological Mission, seasons 2011-2012. Ägypten and Levante 24, 41-122.

Rzepka, S., Hudec, J., Jarmużek, Ł., Dubcová, V., Hulková, Odler, M., L., Wodzińska, A., Trzciński, J., Šefčáková, A., Sójka, P., Fulajtar, E., Černý, M., Tirpák, J., 2015. From Hyksos settlers to Ottoman pipe smokers. Tell el-Retaba 2014. Ägypten and Levante 25, 97-166.

Welc, F., Trzciński, J., 2013. Geology of the Site, In: F. Welc, J. Trzciński, M. Kaczmarek, I. Kozieradzka-Ogunmakin, A. Kowalska, T.I. Rzeuska, Z. Godziejewski with a contribution by W. Weker, Geology, Anthropology, Finds, Conservation, Saqqara V, Old Kingdom structures between the Step Pyramid Complex and the Dry Moat, K. Myśliwiec (Ed.), Varsovie 2013, Part 2, 323-343. 